\title{
THE INTERNATIONAL TRADE OF TELEVISION PROGRAMS IN THAILAND IN THE AGE OF DISRUPTIVE TECHNOLOGY
}

\author{
Sudthanom Rodsawang* \\ Dhurakij pundit University, Thailand
}

\begin{abstract}
This article studied the evolution and characteristics of the international trade of TV programs in Thailand as a guideline for TV station executives and TV program producers to identify an opportunity to develop their media business amidst the changing technology and audience behavior in the age of disruptive technology. The research methods included documentary analyses and interviews with mass media scholars, TV station executives, and advertising agency representatives. Most of the popular TV programs at present are copyright shows purchased from overseas, in the forms of purchases of the copyrights of finished programs as well as the copyrights of format programs; most of which were game shows, reality shows, and drama series. The characteristics of the international trade of the TV programs in Thailand included (1) trade of TV programs in the content market, (2) exchanges of TV programs between Thai and international TV stations for broadcasting, and (3) international co-productions of TV programs. Three factors that influenced TV stations in Thailand to purchase foreign TV programs were (1) changes in technology, (2) changes in consumer behavior, and (3) business survival. Therefore, the international trade of TV programs is another solution for TV stations and TV program producers in Thailand to reduce production costs, increase revenues, and expand the audience base worldwide. TV programs that are popular among a great number of audiences can serve as exported products and cultural products.
\end{abstract}

Keywords: International trade of TV programs, franchised TV programs, TV program copyrights, TV market in Thailand

\section{Introduction}

The competition in the television industry in Thailand has been dramatically increased since the birth of the digital television. As a result, twenty-five (25) digital channels were founded over a very short period of time to serve the market and compete for market shares against the original six (6) analog channels that have been the major players in the market. Moreover, the changing of technology is growing by leaps and bounds. Nowadays, new technology becomes an important factor that greatly influences people's lifestyle. This phenomenon tremendously affects the business sector. Thai television industry in general has been in the downfall while the international trade of television programs in Thailand has increased a lot when comparing to the past.

Assoc. Prof. Dr. Varakorn Samakoses mentions: "The definition of "Disrupt" is to interrupt an event, activity, or process by causing a disturbance or destroy the structure of something. Therefore, the Age of Disruptive Technology is the age that new technologies will be a prime factor that causes changes in people's behavior and markets (Bangkokbiznews, 2016). Therefore, "Disruptive Technology" refers to the innovations or the creations of technologies that create values and markets for technology-based products as well as replacing or disrupting the existing technologies. Disruptive technology has usually been designed to defeat the already-in-use technology, for example, cassette tapes were replaced by audio CDs and then the audio CDs were replaced by music streaming, among others.

The current viewing habits or behavior of the audiences have dramatically changed and have become more diversified. They are more inclined to embrace social media more than traditional television broadcasts. Some of 
them even watch and chat with their friends about a television program via their mobile phones on the same time. It means the traditional television broadcast business model is now being impacted by the said disruptive technology.

According to the research of Google Thailand in collaboration with Taylor Nelson Sofres Research International (Thailand) Ltd. (TNS) using data gathered from 1,000 on-line viewers in January to May 2016 in Thailand, Youtube has long been the main option for watching online VDOs. However the viewing behavior has gradually changed from the previous research. It was found that $61 \%$ of the viewers have watched VDO via Youtube more than television, and $62 \%$ have watched other contents via Youtube more than television, especially amongst the 16-24-year-old age-group. This is because they can precisely select the program according to their interests anytime, which they much prefer to the fixed program schedule normally found on the traditional television broadcasts (Positioning, 2016). Thus, the contents of television broadcasts are the key. A television program that has good content and design will attract the audience.

Furthermore, the birth of digital television in Thailand and the changing of audience behavior have created "television rating battles" among television stations. Each television station has to extremely compete via strategizing their strategies, developing television program contents according to the tastes of their viewers and creating outstanding programs in order to prevent the rating decline.

Economic Intelligence Center of Siam Commercial Bank (SCB EIC) reported that the popularity of dramas after evening news has steadily declined. At the beginning of 2017, the numbers of television drama viewership dramatically decreased, regardless of the fact that famous actors were in the scenes. It can be said that the television stations cannot use the old method to attract the audiences' attention. On the other hand, Workpoint Entertainment Channel broadcasted "The Mask Singer," that they purchased the copyright to this television program from South Korea, has significantly boosted their channel's rating during the prime time period (between $8 \mathrm{pm}$ to $10 \mathrm{pm}$ ). The rating reached 10.93 on March 16, 2016. This phenomenon has raised awareness about the power of licensed television programs from South Korea, and has become the talk of the town for viewers of all ages on the online media (Thaipublica, 2017).

Lately, new television programs are replacing the old TV shows that have long been on the lists. If considered carefully, it is most likely to find similar formats reflected in new television programs shown on many channels, which are TV programs with copyrights purchased from various countries, such as, The Voice Thailand and Thailand's Got Talent broadcast on Channel 3; Master Chef Thailand, Iron Chef Thailand and The Money Drop Thailand broadcast on Channel 7; Identity Thailand and My Man Can broadcast on Channel 9MCOT HD; The Mask singer and I Can See Your Voice broadcast on Channel Workpoint. This phenomenon reflects the new trend that the television station executives and producers prefer buying copyrights of TV programs from overseas.

The International Trade of Television Programs in Thailand can be an alternate guideline for TV station executives and program producers to consider media business development opportunities amidst the changing technology and audience behavior in the age of disruptive technology. The objectives of this article are to summarize the evolution of the international trade of television programs and to classify the characteristics of the international trade of television programs in Thailand. The research methods include documentary analyses, especially news, and interviews with mass media scholars, TV station executives, and advertising agency representatives.

\section{The Definition of the International Trade of Television Programs}

The international trade in television programming has increasingly played important roles in the Thai television industry since the internet has made the world somewhat borderless. The viewers can watch various television programs from around the world. Thus, the international trade of television programs has become a key influence in the television market in the age of disruptive technology. 
Moran started talking about the international trade of television programs as a practice of TV program format franchising that gradually gains a warm welcome in the international television industry (Moran 2009).

"The second, more recent mode is format programming (Moran 1998; Moran and Malbon 2006). Under the system, a program is devised, produced and broadcast in one territory. Subsequently, the program's format is made available as a set of services or franchised knowledges, which allow the program to be adapted and produced for broadcast in another territory. Various advantages attach to this kind of program remaking. Only successful, popular programs become the object of adaptation as foreign producers attempt to insure against ratings failure. The adaptation involves local production labour and can, for regulatory and other political purposes, count as local content." (Moran, 2009, p.117)

Furthermore, Chalaby wrote the article about the evolution of the format trade that the super-formats became apparent in the last decade of the $20^{\text {th }}$ century. They became mega brands and were turned into global franchises (Chalaby, 2012, p.48).

In conclusion, the international trade of television programs is a concept that television programs from overseas can be traded for copyrights and the buyer has to pay certain fees to gain licenses for making duplications. The trade can be in the forms of 'finished TV shows' or 'TV formats.' However, the procurement of the copyrights will be made only with the successful and popular programs amongst the viewers in the originating countries.

Nevertheless, in the television industry, no one can predict whether or not a TV show will be popular until it is broadcasted. For example, one of the most famous TV shows in the world is "Britain's Got Talent," which is a reality show from the United Kingdom, has reflected this fact through the phenomenon of a contestant named Susan Magdalane Boyle. Along with her story, the singing talent of Ms. Susan Magdalane Boyle, who sang "I Dreamed a Dream" in Britain's got talent 2009, impressed the audiences worldwide. This phenomenon has made the "Britain's Got Talent" to become a TV show that many countries bought its copyright to broadcast including Thailand that named the program "Thailand's Got Talent."

\section{The Evolution of the International Trade of Television Programs in Thailand}

The international trade in television programming has been in Thailand for quite some time; yet, it was obvious. In 1980s, many popular television programs in Thailand were series with copyrights from Hong Kong, Japan and South Korea, as well as copyright documentaries from other countries. All of them were in the dubbed format and can be referred as the "finished programs."

The first imported 'format program' in Thailand was the program titled the "Weakest Link." It was originally produced and broadcasted by BBC in the United Kingdom in 2000. The Thai Television Channel 3 bought its copyright and broadcasted in Thailand in 2002. However, it was not well received by the Thai viewers because its content did not correspond to the context of Thai culture and society.

There was also another famous reality show that has been popular for twelve (12) seasons in Thailand which is "True Academy Fantasia," licensed TV format from "La Academia," a popular reality TV show from Mexico. It was a singing contest, judged through popular votes. The contestants were selected through nationwide auditions, as well as through online audition clips. The live auditions took place in major cities in every part of Thailand to search for those who dream about becoming superstars. Four judges would eliminate thousands of people down to top hundred, then approximately last twelve finalists were chosen to go to the Academy House to be mentored. True Academy Fantasia broadcasted from June 21, 2004 - September 19, 2015.

Nowadays, global format programs have occupied prime time in Thai TV schedules, particularly the programs on talent shows and singing contests, for example, Thailand's Got Talent, The Voice Thailand, Master Chef Thailand, The Face Thailand, The Mask Singer, among others. However, there are many licensed TV programs that were not successful in Thailand, namely, 'The Winner Is Thailand,' imported from Talpa Media Group from Netherlands and broadcasted on Channel 3 for only two seasons from 2014 - 2015; 'Don't Lose The 
Money Thailand,' imported from USA in 2014 and broadcasted on Channel 3 just a few episodes and then quietly disappeared from air time. Same situation also hit Workpoint who bought a format TV program titled 'My Little Television' from Munhwa Broadcasting Corporation (MBC), South Korea. In Thailand, this TV program was renamed to 'Battle TV' and only thirteen (13) episodes were broadcasted in 2017. The program was canceled as it was badly received by the audiences.

When take a closer look at the rating in the digital television category during March 26 - April 1,2018, the top five were Thai Television Channel 3, Channel 7, Channel MONO29, Workpoint Channel and Channel 8. Most of the popular television programs of these five digital television channels are currently imported from overseas via purchasing the copyrights of the finished programs and format programs; for example, Thailand's Got Talent, The Face Thailand, Master Chef Thailand; and many popular series, namely, CSI, NCIS and The Walking Dead, among others (TV Digital Watch, 2018).

Meanwhile, Thai producers realize the importance of the international trade of television programs, particularly in the field of 'format program.' Workpoint Channel has started to export their programs to increase its revenues; for example, the copyright of the program titled "Lan - Puu - Kuu - Ii - Juu" (Grandchild Get Fish Trap Out of the Water) was sold to a producer from Vietnam; "Mai - Mod - Nii" (Mic on Debt Off) was sold to a producer from Indonesia and was renamed to "Mikrofon Pelunas Hutang; and "Prisna - Fa - Laeb" (The Flash Quiz) was sold to a producer from the USA. "Super Muay Thai Show" was interestingly sold to a producer from France as a 'finished program.'

\section{Types of Television Programs in International trading}

At present, most television programs are copyright. They can be divided into two groups: the finished program category and the format program category.

- The Purchase of Copyright of the "Finished Program"

The copyright in finished program is a common practice in the television trading industry. "TV production companies based in one country produced TV shows for their own national market and then exported those TV shows to another country, in a dubbed form" (Mirrlees, 2013, p.191). Most of these programs are documentaries, films and series that are ready to be broadcasted which require only Thai dubbing or Thai subtitles. The finished programs can reduce production costs of copyright buyers. However, the TV station that realizes the importance of buying the finished programs' copyrights is Channel Mono 29. This TV station has announced their channel strategy that focuses on buying foreign copyrights in the form of "finished program." Under the "Good Movies and Famous Series" slogan, this strategy demonstrates the channel's strength that creates a good rating which continues to increase. The channel was ranked the $3^{\text {rd }}$ in the country in the beginning of 2018.

- The Purchase of Copyright of the "Format Program"

The trade in TV formats is relatively new. It can also be called "global TV format" or "TV format franchising."

"In the global TV format trade, national TV networks purchase a license to make a domestic version of a foreign TV format from another company. The TV format trade involves a collaborative global-local business relationship between many different national media corporations, based in many different countries" (Mirrlees, 2013, p.192).

The format program is getting the rights for duplications. Copyright buyers must produce TV programs according to the copyright owners' rules and adjust the contents to suit the tastes of audiences in the targeted countries.

The format program category requires professional staffs and has high production costs. Workpoint Channel is an outstanding TV station for format program licensing because the company is equipped with budgets and 
qualified staffs. Although some programs may not be as successful as the original versions, Workpoint still realizes the importance of buying the format programs to attract the audience attention and learn by trial and error to develop their TV programs. In the beginning of 2018, Workpoint was ranked the $4^{\text {th }}$ out of twenty-five (25) channels. The popular format programs that are licensed in Thailand are game shows, reality shows and series. The details are as follows:

Table 1 Lists of Copyright Format Game Shows in Thailand

\begin{tabular}{lll}
\hline \multicolumn{1}{c}{ Programs } & Copyright From & Broadcast On \\
\hline Junior Master Chef Thailand & Australia & 3 \\
\hline Master Chef Thailand & United Kingdom & 7 \\
\hline Iron Chef Thailand & Japan & 7 \\
\hline Identity Thailand & USA & 9 MCOT HD \\
& & $(2013-2014)$ \\
& & Workpoint (2016) \\
\hline Take Me Out Thailand & United Kingdom & 3 \\
\hline My Man Can & Germany & 9 MCOT HD \\
(Original version: Mein Mann Kann) & & $(2014)$ \\
& & Workpoint (2015) \\
\hline I Can See Your Voice & South Korea & Workpoint \\
\hline Dance Your Fat Off & USA & 3 \\
\hline
\end{tabular}

Table 2 Lists of Copyright Format Reality Shows in Thailand

\begin{tabular}{lll}
\multicolumn{1}{c}{ Programs } & Copyright From & Broadcast On \\
\hline Thailand's Got Talent & United Kingdom & 3 \\
\hline The Voice Thailand & Netherlands & 3 \\
\hline True Academy Fantasia & Mexico & True Visions \\
\hline The Face Thailand & USA & 3 \\
\hline $\begin{array}{l}\text { The Mask Singer } \\
\text { (Original version: Miseuteori Eumaksyo } \\
\text { Bokmyeon-gawang) }\end{array}$ & South Korea & Workpoint \\
\hline The X Factor Thailand & & \\
\hline Let Me In Thailand & United Kingdom & Workpoint \\
\hline
\end{tabular}


Table 3 Lists of Copyright Format Series in Thailand

\begin{tabular}{lll}
\hline \multicolumn{1}{c}{ Programs } & Copyright from & Broadcast on \\
\hline $\begin{array}{l}\text { Wun Nak Ruk Tem Baan } \\
\text { (Original version: Full House) }\end{array}$ & South Korea & True 4 U \\
\hline $\begin{array}{l}\text { Likit Rak Kham Duangdaw } \\
\text { (Original version: You Who Came From } \\
\text { The Stars) }\end{array}$ & South Korea & 3 \\
\hline $\begin{array}{l}\text { You Are my Destiny } \\
\text { (Original version: Fated to Love You) }\end{array}$ & South Korea & One \\
\hline $\begin{array}{l}\text { Onlaweng Rak Salub Rang } \\
\text { (Original version: Secret Garden) }\end{array}$ & South Korea & True 4 U \\
\hline Oh My Ghost & South Korea & True 4 U \\
\hline $\begin{array}{l}\text { 18 Mongkut Sud Thirak } \\
\text { (Original version: My Girl) }\end{array}$ & South Korea & True 4 U \\
\hline $\begin{array}{l}\text { Rak Ni Chou Ni Ran } \\
\text { (Original version: Autumn in My heart) }\end{array}$ & South Korea & True 4 U \\
\hline $\begin{array}{l}\text { Rak Wunway khong Chaw Chay Café } \\
\text { (Original version: Coffee Prince) }\end{array}$ & South Korea & True 4 U \\
\hline Princess Hours & South Korea & True 4 U \\
\hline Gossip Girl Thailand & USA & 3 \\
\hline $\begin{array}{l}\text { Yai Ped Khi Ray } \\
\text { (Original version: Ugly Betty) }\end{array}$ & USA & 32 \\
\hline $\begin{array}{l}\text { Kiss Me } \\
\text { (Original version: Itazura Na Kiss) }\end{array}$ & Japan & True 4 U \\
\hline
\end{tabular}

\section{The Characteristics of International Trade of Television Programs in Thailand}

The characteristics of international trade of television programs in Thailand include:

- $\quad$ Trade of TV Programs in the Content Marketing: The content marketing is an event for buying, selling, financing, co-producing and distributing TV, films, and digital and audiovisual contents. It is a meeting place for business talks. Such events are, for example, MIPCOM (Le Marché International des Programmes Communications) in France, NATPE Miami (National Association of Television Program Executives), HKTDC Hong Kong FILMART (Hong Kong Trade Development Council) and Asia TV Forum \& Market in Singapore, among others.

- Exchanges of TV Programs between Thai and Overseas TV Stations for Broadcasting: The exchange is only possible if there is a good relationship between two television stations from two different countries. They can sign MOU to exchange the TV programs for broadcasting.

- International Co-Production of TV Programs. Co-production refers to the processes which programs are co-produced and share production costs and processes. The international co-production started in Thailand between the Thai and South Korean production houses for a film named "20 Mai Hua Jai Return" or its adaptation is "Miss Granny." However, the TV co-production requires further studies. Promoting a joint venture and co-production can expand opportunities to create revenues and develop high-quality contents. 


\section{Conclusion}

The purchase of copyrights of TV programs from overseas will normally guarantee that the purchased programs are likely to be popular and increase the audiences' attention. Therefore, the international trade of TV programs is an achievement shortcut for companies and television stations in this highly competitive era.

The three major influence factors that make TV stations in Thailand purchasing foreign TV programs are technology innovations, the changes in audience behavior and business survival.

First, as a result of the technology innovation, the production techniques and media business models inevitably require changes. People can watch TV programs from Youtube, Line TV, Facebook or TV stations' platforms, such as, Mello (Channel 3) and Bugaboo (Channel 7). Therefore, producers should consider adjusting or changing the production formats and business models accordingly.

Second, audience behavior has changed. The audiences have watched television programs and rewatched them from Youtube. They are also inclined to watch the programs that receive high attention or feedbacks from social media posts and/or shared messages on the online media believing they are trendy programs.

The last factor is business survival. The international trade of TV programs is another solution for TV stations and TV program producers in Thailand because it helps reducing production costs, increasing revenues, and expanding the audience base worldwide. This story shows that the content is always the key. TV programs that are popular among a great number of audiences can be exported as media products and cultural products.

However the success and sustainability of the international TV program trade in Thailand will be based on their responses to the tastes and preferences of Thai consumers.

\section{References}

Chalaby, J. K., 2012, At the origin of a global industry: The TV format trade as an AngloAmerican invention. Media Culture and Society, 34(1), 36-52.

Hale, H., 2018, How to work the film \& TV markets : A guide for content creators.

(New York, USA.: Routledge).

Kaewthep, K., 2009, Media analysis Concepts and techniques. (Bangkok, Thailand:

Parbpim Limited Partnership). (In Thai).

Mirrlees, T., 2013, Global Entertainment Media: between cultural imperialism and cultural Globalization. (New York, USA.: Routledge).

Moran, A., 2009, Global franchising, local customizing: The cultural economy of TV program formats. Continuum: Journal of Media \& Cultural Studie, 23(2), 115-125.

\section{Internet sources}

Bangkokbiznews, Samakoses, V., Understanding Disruptive Technology, Date of access: 20/12/2017. http://www.bangkokbiznews.com/blog/detail/639505. (In Thai).

Positioning, Thai behavior has changed. $61 \%$ of the viewers have watched VDO via Youtube more than television, Date of access: 15/11/2017. https://positioningmag.com/1105638. (In Thai).

Prachachart business, Workpoint moved the big model to export their programs, Date of access: 15/11/2017. http ://www.prachachat.net/news_detail.php?newsid=1381390772. (In Thai).

Thaipublica, EIC reported that the popularity of dramas after evening news has steadily declined, 
Date of access: 15/11/2017. https://thaipublica.org/2017/03/eic-war-on-advertising-revenue/.

(In Thai).

Thaipublica, Luengnaruemitchai, P., Disruptive Technology and investment, Date of access:

20/12/2017. https://thaipublica.org/2016/07/pipat-48/.(In Thai).

TV Digital Watch, 25 ratings in the digital television, Date of access: 5/4/2017.

http://www.tvdigitalwatch.com/category/rating-25-channels/. (In Thai).

\section{Interviews}

Common, T.B., lecturer, Department of Mass Communication, Faculty of Communication Arts, Chulalongkorn University, Bangkok, Thailand, interview with author, 17/12/2017.

Jutimanon, T., Director of Channel 9 MCOT HD, Mass Communication Organization of Thailand Public Company Limited (MCOT), interview with author, 20 /12/2017.

Reanthong, M., Communications Director, Ogilvy \& Mather Advertising (Thailand), interview with author, $13 / 1 / 2018$. 